\title{
Research on Fire: Lessons Learned in Knowledge Mobilization Susan Braedley
}

\author{
"When one burns one's bridges, what a very nice fire") \\ it makes.
}

\author{
Dylan Thomas (1914-1953) \\ Poet and writer
}

\begin{abstract}
In this article, I outline knowledge mobilization lessons learned while working on politically "hot button" issues in public policy research related to fire services. These lessons were shaped by the research funding context. Researchers are increasingly required to develop research relationships with government, industry, and community partners to ensure research is relevant to those who can best use it, to embed knowledge mobilization in research processes, to ensure that knowledge has an impact in the world beyond the academy, and to provide research funding. Perhaps not surprisingly, when my findings created challenges for research partners, controversies erupted, potentially imperiling my research program, career, and potential research impact. Drawing from my knowledgemobilization experiences as well as those of other researchers, I offer some insights gained from mobilizing knowledge on a "hot topic" in public policy.
\end{abstract}

\section{Introduction}

Lurking within the new politics of university research are two interlocking hazards for public policy researchers: first, the requirement for research partnerships and second, latent conflicts of interest within these partnerships. These hazards may be invisible or suppressed until knowledge mobilization, when they can erupt into flame. As an academic whose research on municipal fire services almost ended in a knowledge mobilization firestorm, I found very little in the research literature on dealing with these challenges. In what follows, I offer some lessons learned along my research path. I begin by describing and illustrating these hazards through the experiences of researchers in a Dutch research consortium. Next, I describe my own experiences in addressing these hazards and share some lessons learned that may be useful to others conducting research with public policy dimensions. I conclude with some thoughts and suggestions about how universities and funding bodies can better support researchers who aim to contribute to public policy debates.

\section{Two Hazards, Two Questions}

Across many countries, including Canada, university research funding infrastructures have been significantly re-tooled and reorganized. The first hazard of this new university research funding infrastructure is the increasing reliance on external partnerships, including funding from external stakeholders and corporate partners. In Canada and elsewhere, government-funded granting agencies now commonly require these arrangements, with the explicit goal of making research more directly relevant to stakeholders. But these partnerships and funding arrangements suggest a critical question. Whose interests should guide funded university research on public policy? In fields such as medicine, agriculture, energy and climate change, partnerships and corporate funding have influenced research projects to serve the profit motivations of partners, sometimes at the expense of researcher integrity, wider public interests, and more pressing public issues (Brownlee, 2015; Mirowski, 2011). This concern is also emerging in public policy-oriented research. While public benefit remains a priority for Canadian granting agencies (SSHRC, 2016), what counts as public benefit may be limited in some cases to issues such as value for tax dollars or accountability (Estabrooks et al., 2008) that often benefit elite stakeholders at the expense of others, as the example that follows illustrates.

In the Netherlands, a well-respected research consortium won a government contract to conduct a review of 


\section{Research on Fire: Lessons Learned in Knowledge Mobilization}

Susan Braedley

childcare quality. A scientific advisory board of stakeholders, including providers and government, was involved with the research team. In 2005, the research findings showed that over a third of the country's daycare centres had poor quality, which was a significant net drop in quality since a similar review in 2001. Further the research revealed that Dutch day care quality lagged when compared to countries such as Canada and Germany. From a researcher perspective, the knowledge mobilization process went well. The report made front-page news, generating significant public debate. In response, the government went back to the research consortium to commission a more extensive daycare quality survey. However, one of the stakeholders, a forprofit daycare provider, organized a boycott of the new survey, successfully blocking research access to many centres while retaining membership on the consortiums' scientific advisory board. Despite a ministerial reprimand, the agency continued its boycott, finally influencing the government minister to request changes to the research proposal to accommodate its concerns. These politics split the consortium, with one large group of researchers exiting the project on ethical grounds, leaving their research program and milliondollar funding behind (van IJzendoorn \& Vermeer, 2015).

The second hazard, related to the first, is that conflicts between and among partner and public interests can lay dormant or unexpressed until research findings go public. Knowledge mobilization, as the latest iteration in the field of knowledge dissemination, transfer, translation, and exchange, has developed as an integral aspect of the increasing emphasis on research partnerships. Conceptualized to produce a closer relationship between evidence and practice, integrated knowledge mobilization is a systems approach in which knowledge users and researchers work together throughout the research process, from formulating research questions to sorting out how best to put evidence in practice (Baines, 2007; Levin, 2013). Public dissemination and accessibility are usually considered important components of research oriented toward public policy, but as the Dutch childcare case demonstrates, they can also be explosive. Some context makes the reasons for this controversy clearer. In 2005, seeking to increase the supply of daycare, the Netherlands government enacted legislation that switched the publicly funded supply-side childcare system to market provision. Almost overnight, publicly funded daycare centres were gone, replaced by a $60 / 40 \%$ mix of forprofit providers and private non-profit centres (Akgun- duz \& Plantenga, 2015). The survey findings suggested that this switch to market provision had resulted in quality reductions and access inequities for lower-income households (Noailly \& Visser, 2009). These findings suggest that government policy - aimed narrowly at increasing the daycare supply with a minimum of public investment - offered a profit opportunity to business owners at the expense of daycare quality and accessibility for low-income parents. Researchers did an excellent job informing the public but at least some providers reacted strongly to protect their corporate interests, while the government, implicated due to the policy change, sided with providers. In turn, the researchers' academic freedom was reduced to a choice between compromising or walking away.

This second hazard provokes the question of values. In any given project, what values are guiding research processes? In considering the daycare case, were the values that guided the project commitments to improving equity, access, quality of service, good working conditions, social inclusion, and to maximize efficiency, choice, supply, and accountability? Which values ranked as more important than others? This consideration calls into question the assumption that researchers are, or ever can be, neutral observers, for research questions themselves contain assumptions about values and interests, even if research teams never acknowledge or discuss them. Indeed, as Harding (1995) points out, attempts at neutrality can block objectivity, preventing the necessary work of surfacing values.

Knowledge mobilization can and, in my view, should promote "catalytic validity" (Baines, 2007; Lather, 1986): a process in which knowledge shifts, re-orients, or energizes those engaged in a particular reality so that they may pursue transformations. In order to achieve this goal, some alignment of values must be achieved among the partners, including the academic researchers. But even when there is such alignment at the outset, political shifts affecting research partners can change it significantly. There are no guarantees. Attention to shifting priorities within a research project is particularly necessary in public policy and services research.

\section{Learning the Hard Way}

My experience in public services research provides another example of knowledge mobilization as a potential flashpoint in research partnerships. As a social sciences researcher whose work is informed by femin- 


\section{Research on Fire: Lessons Learned in Knowledge Mobilization}

Susan Braedley

ist anti-racist political economy (Luxton 2006), my research program focuses on social policies that affect care, including who provides, receives, and pays for care. I begin with the overt emancipatory objective to contribute knowledge that improves the conditions of care for vulnerable people and the conditions of work for those who provide their care. I brought this program to Canadian professional fire services, who have been roundly criticized for employment inequities and, at the same time, have been thrust into providing significant emergency support for many sick and suffering people. Some fire services signed on, agreeing to work with me to identify: i) promising practices in employment equity, both in terms of including women and under-represented minority groups as firefighters and ii) an assessment of their involvement in emergency response (i.e., 9-1-1, 999, 112, or 000 in most countries) to medical and social care emergencies as a significant shift in fire services' hyper-masculinized work. These issues were and remain controversial within fire services. In total, five of the original eleven fire services withdrew from the study, each indicating concerns about the potential backlash from research findings that could jeopardize already contentious relationships with city councils. Three others signed onto the study part way through, each with its own aims and goals for participation. As a solitary investigator, I watched research doors open and close in dizzying succession through the three-year project, often wondering if I would be able to complete the project at all.

I struggled along. In the summer of 2015, after reporting my findings-to-date at several industry conferences, in a publicly available report, and in a peer-reviewed academic journal, my research on fire services involvement in emergency medical response was covered in a short item in the Toronto Star, a major Canadian newspaper. The article (Mendleson, 2015) correctly stated that my research suggested that fire and paramedicine responses required closer integration to improve service delivery. Further, I had commented that debates about whether or not fire services should be involved in emergency medical responses were not likely going to alter the status quo, given that 9-1-1 calls were steadily increasing, paramedic services were stretched beyond capacity, fire services had capacity to assist at low cost, and there did not seem to be any political will to change the situation.

For some paramedics, firefighters, and emergency services organizations, these statements were perceived as an attack. Paramedics who were struggling for jobs, services expansions, and recognition as health professionals were angry, as were firefighters who opposed increased involvement in "medicals" as mission drift. Efforts to discredit me - as opposed to my findings began. Although the news item was posted on lazy summer Saturday, my email filled immediately with messages of with hate, attack, and vitriol (from both paramedics and fire fighters) as well as disturbing messages of support that misinterpreted my position to mean that I thought firefighters should - or should not - be involved in emergency medical care. There were also vaguely threatening anonymous phone messages and denigrating tirades on industry-related websites. Some members of a large public services union were very angry with me. I have worked with this union since 2010 on several projects, and I worried that the resentment by one group might imperil my research relationships throughout the union. In September, two fire services withdrew from my study and another stopped communication without explanation. In October, a group of paramedics walked out of a talk I gave at a large union meeting. My research funding was due to expire in December and opportunities to conclude my study were evaporating. Further, my future research program that included research with both fire fighters and paramedics was looking like an impossible dream. I was also up for tenure and promotion. I worried that my career advancement and future research funding opportunities were evaporating. I spent many days away from teaching and writing, trying to build and retain research relationships.

But beyond these more personal worries, the original goals and values of this research were getting lost. What about improvements to employment equity for women and other groups left out of public firefighting work? What about improving services for the poor, marginalized, and suffering people who relied upon 9-1-1 as often their only accessible support service? It was a low moment in my research career.

\section{Knowledge Mobilization Is Politics}

These examples of researcher experience demonstrate that knowledge mobilization processes in public policy research are deeply political. Given the terrain, it is somewhat surprising that the knowledge mobilization literature has so little to say about political controversy (Estabrooks et al., 2008; Goering et al., 2010; Jacobson et al., 2003; Levin, 2013; Ward et al., 2010). Between research funding requirements and the challenges involved in gaining access to research sites, the need for 


\section{Research on Fire: Lessons Learned in Knowledge Mobilization}

Susan Braedley

research "partners" is putting pressure on research programs - as no doubt they are designed to do - to align with the political goals and values of "stakeholders" in exchange for research opportunities. To opt out of these politics may be possible for some researchers, but for others, it is a career-ending move. However, there are alternatives. Below, I outline some of my lessons learned through my fall into the knowledge mobilization political soup.

I did get a few crucial things right. First, a clear articulation of research project values and goals in research access agreements has proved to be an enduring touchstone, helping me and my research partners stay clear on the project's ultimate goals. These agreements were made in writing prior to beginning research at each fire service and kept me honest when desperation for access made compromise look like a sensible option. Second, rather than allow research drift justified by "stakeholder input", I returned to these agreements when concerns emerged. Third, I used this agreement review not as a sledge hammer but as an opportunity to open space, to listen, and to gain clarity and mutual understanding. Although some fire services left the project, this open communication has maintained my relationships with the people involved, who continue to provide opportunities for me to share findings and maintain dialogue. I was able to complete the project with the goals and objectives intact, albeit not as originally planned.

I also got a few things spectacularly wrong. First, I did not develop relationships with or include stakeholder groups whose goals and values aligned most closely with the research program. I needed to partner with fire services in order to gain access, and I hoped to create evidence that would stimulate change within them. But, due to worries about managing too many relationships and expectations, I did not include equity-seeking groups or groups committed to health equity - the people supposedly central to the research objectives. This was a mistake. If these groups had been included, my research might have taken a different trajectory. It would not have avoided controversy, but with other voices and interests to consider, the project would likely have proceeded differently, offering other possibilities and advice when partners withdrew or came on board.

A second mistake was to take on sole responsibility for knowledge mobilization. After reviewing some of the findings, my fire services research partners advised me that if knowledge mobilization proceeded as planned at the proposal stage, with services, unions, or fire chief associations sharing in dissemination, the project would be discredited as "biased" due to the increasingly volatile politics within the emergency services field. Research has shown that sharing knowledge mobilization with third parties can produce more research uptake (Levin, 2013). Perhaps if I had involved equityseeking groups from the outset, I might have had alternatives. In the end, my options were limited and my knowledge mobilization goals for this project have yet to be fully realized.

I continue to reap the benefits and pay the price for my decisions, right and wrong. I continue to do knowledge mobilization on this project, unfunded, one relationship at a time, which has included productive discussions with some of the very paramedics who initially attacked and walked out on me, as well as with federal and municipal governments interested in policy change and services improvements.

\section{Conclusion}

If public policy-oriented researchers are to take up contentious issues and challenge conventional approaches, we must be prepared for controversy, both within and beyond our research partnerships. But this preparation could be better supported by research funders, university research departments, and university tenure and promotion structures. First, if our research is to serve a broad range of public interests, universities and funders must continue to develop knowledge mobilization funding that acknowledges the time it takes both during and after the research process to produce impact. Further, there must be more recognition that funding structures that require contributions from research partners privilege research partners with resources to contribute, potentially sidelining the interests of groups without resources. Thirdly, university research departments can enhance training on building and maintaining research relationships, including training on research agreements, knowledge mobilization, dealing with controversy, and how to deal with issues that may necessitate ethical withdrawal, including dealing with funders.

Finally, while university tenure and promotion structures are beginning to recognize knowledge mobilization in some ways, there is a long way to go. There is little status but some recognition for non-academic speaking and writing. However, researchers are not 


\section{Research on Fire: Lessons Learned in Knowledge Mobilization}

\section{Susan Braedley}

credited for the time, skill, and creativity required to develop and maintain research relationships that produce strong knowledge mobilization and particularly those that that can support "catalytic validity". Building and maintaining these research relationships is a topic worthy of its own discussion, just beginning in the research literature (Hofmeyer et al., 2012; Reyes, 2013). Without explicit support from universities and funders, researchers' abilities to pursue meaningful and highimpact research oriented on public policy will be hampered, no matter how many lessons we have been learned.

\section{References}

Akgunduz, Y. E., \& Plantenga, J. 2015. Equal Access to High Quality Child Care in the Netherlands. In L. Gambaro, K. Stewart, \& J. Waldfogel (Eds.), An Equal Start? Providing Quality Early Education and Care for Disadvantaged Children: 101-120. Bristol, UK: Policy Press.

Baines, D. 2007. The Case for Catalytic Validity: Building Health and Safety through Knowledge Transfer. Policy and Practice in Health and Safety, 5(1): 75-89.

http://dx.doi.org/10.1080/14774003.2007.11667689

Brownlee, J. 2015. The Corporate Corruption of Academic Research. Alternate Routes: A Journal of Critical Social Research, 26: 23-50.

Estabrooks, C. A., Norton, P., Birdsell, J. M., Newton, M. S., Adewale, A. J., \& Thornley, R. 2008. Knowledge Translation and Research Careers: Mode I and Mode II Activity among Health Researchers. Research Policy, 37(6): 1066-1078.

http://dx.doi.org/10.1016/j.respol.2008.04.006

Goering, P., Ross, S., Jacobson, N., \& Butterill, D. 2010. Developing a Guide to Support the Knowledge Translation Component of the Grant Application Process. Evidence \& Policy: A Journal of Research, Debate and Practice, 6(1): 91-102. http://dx.doi.org/10.1332/174426410X483024

Harding, S. 1995. "Strong Objectivity": A Response to the New Objectivity Question. Synthese, 104(3): 331-349.

http://dx.doi.org/10.1007/BF01064504

Hofmeyer, A., Scott, C., \& Lagendyk, L. 2012. Researcher-DecisionMaker Partnerships in Health Services Research: Practical Challenges, Guiding Principles. BMC Health Services Research, 12(1): 280 .

http://dx.doi.org/10.1186/1472-6963-12-280

Jacobson, N., Butterill, D., \& Goering, P. 2003. Development of a Framework for Knowledge Translation: Understanding User Context. Journal of Health Services Research \& Policy, 8(2): 94-99. http://dx.doi.org/10.1258/135581903321466067

\section{About the Author}

Susan Braedley is an Associate Professor in the School of Social Work at Carleton University in Ottawa, Canada. She is co-editor of Neoliberalism and Everyday Life (McGill-Queens University Press, 2010) and Troubling Care (Canadian Press, 2013), and she is the author of many articles on social policy topics. She is a co-investigator on three largescale comparative studies of long-term care policies and practices (funded by SSHRC and CIHR), as well as principal investigator on the SSHRC funded project "Equity Shifts: Employment Equity in Protective Services". Her research and teaching focus on social policies and their implications for labour, gender, race, and class, and on research methodologies.

Lather, P. 1986. Issues of Validity in Openly Ideological Research: Between a Rock and a Soft Place. Interchange, 17(4): 63-84. http://dx.doi.org/10.1007/BF01807017

Levin, B. 2013. To Know Is Not Enough: Research Knowledge and Its Use. Review of Education, 1(1): 2-31.

http://dx.doi.org/10.1002/rev3.3001

Luxton, M. 2006. Feminist Political Economy in Canada and the Politics of Social Reproduction. In K. Bezanson \& M. Luxton (Eds), Social Reproduction: Feminist Political Economy Challenges Neoliberalism: 11-44. Montreal \& Kingston: McGill-Queens University Press.

Mendleson, R. 2015. How to Stop the Turf War between Firefighters and Paramedics. Toronto Star, July 25, 2015. Accessed July 25, 2015: https://www.thestar.com/news/gta/2015/07/25/how-to-stop-theturf-war-between-firefighters-and-paramedics.html

Mirowski, P. 2011. Science-Mart: Privatizing American Science. Boston: Harvard University Press.

Noailly, J., \& Visser, S. 2009. The Impact of Market Forces on Child Care Provision: Insights from the 2005 Child Care Act in the Netherlands. Journal of Social Policy, 38(03): 477-498. http://dx.doi.org/10.1017/S0047279409003109

Nutley, S., Morton, S., Jung, T., \& Boaz, A. 2010. Evidence and Policy in Six European Countries: Diverse Approaches and Common Challenges. Evidence \& Policy: A Journal of Research, Debate and Practice, 6(2): 131-144. http://dx.doi.org/10.1332/174426410X502275

SSHRC. 2016. Advancing Knowledge for Canada's Future: Enabling Excellence, Building Research Partnerships, Connecting Research to Canadians SSHRC's Strategic Plan to 2020. Ottawa: Social Sciences and Humanities Research Council of Canada (SSHRC).

Reyes, A. G. 2013. Enhancing Expertise of Community Partners to Promote Equity in CBPR: Collaborative Research Capacity Building Training for Community-Based Organizations: A Community Perspective. Paper presented at the 141st APHA Annual Meeting, November 2-6, 2013. Washington, DC: American Public Health Association (APHA). 


\section{Research on Fire: Lessons Learned in Knowledge Mobilization}

Susan Braedley

van IJzendoorn, M. H., \& Vermeer, H. 2015. How to Protect Scientific Integrity under Social and Political Pressure: Applied Day-Care

Research between Science and Policy. In R. Sternberg \& S. Fisk

(Eds.), Ethical Challenges in the Behavioral and Brain Sciences: 212-217. Cambridge: Cambridge University Press

Ward, V., Smith, S., Foy, R., House, A., \& Hamer, S. 2010. Planning for Knowledge Translation: A Researcher's Guide. Evidence \& Policy: A Journal of Research, Debate and Practice, 6(4): 527-541.

http://dx.doi.org/10.1332/174426410X535882

Citation: Braedley, S. 2016. Research on Fire: Lessons

Learned in Knowledge Mobilization. Technology

(cc) BY

Innovation Management Review, 6(9): 53-58.

http://timreview.ca/article/1020

Keywords: knowledge mobilization, public policy, public services, research values, catalytic validity 